\title{
Title: Now casting and Forecasting of COVID-19 outbreak in the National Capital Region of Delhi.
}

Bharathnag Nagappa ${ }^{1}$, Manikandanesan Sakthivel, Yamini Marimuthu ${ }^{2}$, Aayushi Rastogi ${ }^{1}$, Archana Ramalingam ${ }^{1}$, Shiv Kumar Sarin ${ }^{1 *}$,

${ }^{1}$ Institute of Liver and Biliary Sciences, New Delhi-110070, India

${ }^{2}$ Maulana Azad Medical College, New Delhi-110002, India

*Corresponding author

\section{Abstract:}

Objectives: The study aimed to estimate the disease burden due to COVID-19 in the scenarios of unchecked spread and with various public health interventions in New Delhi.

Methods: We adopted Susceptible, Exposed, Infected and Recovered (SEIR) model to estimate the course of COVID-19 outbreak in Delhi population and effect of public health intervention on the pandemic. We first estimated the basic reproductive rate $\left(\mathrm{R}_{0}\right)$ based on the evidence from Wuhan, then ran the model considering no intervention implemented, followed by case isolation, social distancing, and lockdown, each implemented in isolation and in combinations to estimate the number of cases. Markov's model was used to estimate the number of cases in various clinical scenarios of the disease. Sensitivity analysis conducted to estimate the effect of asymptomatic cases on case based interventions.

Results: Estimated $\mathrm{R}_{0}$ in Delhi population was 6.18 (range 4.15 - 12.2). Effective reproductive rate $\left(\mathrm{R}_{\mathrm{t}}\right)$ was least for case isolation (3.5). Lockdown showed highest reduction (28\%) in number of prevalent cases on peak day and $22 \%$ reduction in patients in need of intensive care unit (ICU). Case isolation and lockdown together resulted in 50\% reduction in number of prevalent cases and $42 \%$ reduction in patients in need of ICU care. Sensitivity 
medRxiv preprint doi: https://doi.org/10.1101/2020.05.01.20087783; this version posted May 10, 2020. The copyright holder for this preprint

analysis showed that the effect of case isolation was inversely proportionate to the proportion of asymptomatic (hidden) cases.

Conclusions: Interventions should be implemented in combinations of individual and community level interventions to gain better outcome. Identifying and isolation of all cases as early as possible is important to flatten the pandemic curve.

Key words: COVID-19, mathematical modelling, pandemic, public health interventions, SARS-CoV-2, SEIR model, social distancing

\section{Introduction:}

Clusters of individuals with pneumonia and clinical presentation similar to severe acute respiratory syndrome coronavirus (SARS-CoV) reported from Wuhan in December, 2019. ${ }^{[1,2]}$ On January 12, 2020, a novel strain of coronavirus (severe acute respiratory syndrome corona virus 2 (SARS-CoV-2)) was isolated from these clusters of pneumonia cases and the new respiratory illness named as coronavirus disease 2019 (COVID-19). ${ }^{[3]}$ Evidence suggesting that the Huanan seafood wholesale market was the initial transmission site for the novel virus. ${ }^{[4]}$ The market was closed and disinfection measures were taken to prevent further transmission. ${ }^{[5]}$ Since then Cases of COVID-19 have been reported in health-care workers and family members of cases with 67,794 cases and 3,805 deaths confirmed in Hubei province as of March 15, 2020. ${ }^{[4,6,7]}$ Later the centre of pandemic shifted to Italy and then to the United states which currently accounts for the highest number of cases in the world. Older individuals (aged $>60$ years) and people with chronic health conditions are reported to be more susceptible to severe disease. ${ }^{[6]}$ Rapid spread of the virus led the Chinese Government to restrict movement in affected cities, with the cessation of public transport and cancellation of flights. ${ }^{[8,9]}$ Despite extensive efforts to prevent onward spread, 203 countries and territories outside the mainland of China have reported imported cases. Internationally, ongoing local 
transmission of SARS-CoV-2 has been confirmed in 149 countries and territories. ${ }^{[7]}$ In India, 10,197 tested positive, 1343 cured and 392 deaths related COVID-19 were reported as on $15^{\text {th }}$ April, 2020. ${ }^{[10]}$ India has reported local transmission and may enter stage three of pandemic soon. India had taken measures like, home quarantining all international travellers, national level lockdown, promoting social distancing, tracing and quarantining of contacts of all positive cases to prevent the further spread of diseases. ${ }^{[11]}$ Even with all these measures India is still noticing the increase in COVID-19 cases. Cases were reported among health care workers, family members and other close contacts of COVID-19 cases. There might be an exponential increase in COVID-19 cases in India. Because of asymptomatic cases, under reporting and misdiagnosis, it is difficult for policy makers to understand the exact burden of disease and act accordingly.

Maharasthra followed by the National Capital Region of Delhi, account for the largest number of reported cases in the country today. ${ }^{[10]}$ Modelling studies are needed to understand the disease burden and potential impact of early interventions to guide the policy makers in this early stage of COVID-19 in India.

\section{Material and Methods:}

\section{Epidemiological Model:}

We used Susceptible (S), Exposed (E), Infected (I), Recovered (R) (SEIR) model to estimate the disease burden in the community. Where ' $\mathrm{S}$ ' represents the number of susceptible persons, 'E' represents the total number of persons in latent period, 'I' represents the total infected and symptomatic individuals and ' $R$ ' represents the total people recovered from the disease at the given time $(\mathrm{t}) .^{[12]}$ This model gives insights on the flow of people from susceptible to exposed, exposed to infected and infected to recovered phase. The model considered the relationship between basic reproductive rate $\left(\mathrm{R}_{0}\right)$ and total infectious period to 
estimate the transmissibility coefficient. To estimate the contact probability, we divided the susceptible population by total population. As the infectious period equals to inverse of recovery rate, the model considered one over infectious period to estimate the recovery rate. ${ }^{[13]}$ SEIR model assumes that the population are in closed compartments. ${ }^{[13]}$ But, in the real scenario, many imported cases (with history of travel outside India and tested positive) were reported from Delhi. To adjust for it, we added the imported cases on the reported day into the total infected cases till $14^{\text {th }}$ day of stopping international flights. The SEIR is model given below. ${ }^{[14]}$

$$
\begin{aligned}
& \frac{d S}{d t}=-\frac{\beta I S}{N} \\
& \frac{d E}{d t}=\frac{\beta I S}{N}-\frac{E}{l} \\
& \frac{d I}{d t}=\frac{E}{l}-\gamma I \\
& \frac{d R}{d t}=\gamma I
\end{aligned}
$$

We used Markov's probability model to estimate the mild disease, severe disease, number of patients needing intensive care unit (ICU) admission and deaths due to COVID-19. ${ }^{[15]} \mathrm{We}$ applied daily recovery rate separately for severe and mild diseases, to account for the difference in time to recover from the disease in mild and severe cases.

To estimate the basic reproductive rate of Delhi, we multiplied the population density ratio of Delhi and area where $\mathrm{R}_{0}$ was taken from. ${ }^{[14]}$

$\mathrm{R}_{0}$ in Delhi population $=(\text { Population density of Delhi/population density of Wuhan })^{*} \mathrm{R}_{0}$ in

$$
\text { Wuhan population }
$$

To estimate the effective reproductive rate $\left(\mathrm{R}_{\mathrm{t}}\right)$ when interventions are implemented, we multiplied the reduction fractions (rf) assumed for different interventions (Table I) and basic 
reproductive rate. Community-level interventions are given to all individuals irrespective of diseases status, but individual-level interventions (cases isolation, contacts isolation or quarantine) are limited to cases and their close contacts. Community-level interventions decrease the transmission and prevent the complete spectrum of diseases whereas individuallevel interventions decrease the transmission from only symptomatic/identified cases and would not alter the transmission from asymptomatic/ hidden cases. Therefore, while estimating the number of cases, effect of community level interventions were applied to both asymptomatic and symptomatic cases and effect of individual level interventions were applied only to symptomatic cases. In multiple interventions scenario, effect of community level interventions on $\mathrm{R}_{\mathrm{t}}$ was estimated first, and effect of individual level intervention applied to $\mathrm{R}_{\mathrm{t}}$ of community level intervention.

$\mathrm{R}_{\mathrm{t}}$ in single intervention scenario

$\mathrm{R}_{\mathrm{t}}=\mathrm{rf} * \mathrm{R}_{0}$

$\mathrm{R}_{\mathrm{t}}$ in Multiple intervention scenario

$\mathrm{R}_{\mathrm{t}}=\left(\mathrm{rf}_{\mathrm{ci}}+\left(1-\mathrm{rf}_{\mathrm{ci}}\right) * \mathrm{rf}_{\mathrm{i}}\right) * \mathrm{R}_{0}$

$\mathrm{R}_{\mathrm{t}}-$ effective reproductive rate

$\mathrm{R}_{0}-$ Basic reproductive rate

rf - reduction fraction

$\mathrm{rf}_{\mathrm{ci}}-$ reduction fraction due to community level intervention

$\mathrm{rf}_{\mathrm{i}}-$ reduction fraction due to individual level intervention

\section{COVID-19 infection parameters and assumptions}


medRxiv preprint doi: https://doi.org/10.1101/2020.05.01.20087783; this version posted May 10, 2020. The copyright holder for this preprint

According to 2011 census data, Delhi population was 1.64 crore. ${ }^{[16]}$ Using birth and death rate of we estimated the current Delhi population to be 1.9 crore. ${ }^{[17]}$ In the SEIR model, we assumed that no individual had the immunity against COVID-19 in the study setting. We assumed $2^{\text {nd }}$ March 2020 as day zero, when the first index case reported. There was no data available on parameters of COVID-19 disease in Indian community; hence we used the data from international studies. The parameters included were incubation period $(5 \text { days })^{[4,18,19]}$ of COVID-19, time needed for recovery from disease (7 days for Mild disease and 15 days for severe disease), and time of death from the onset of symptoms (18 days). ${ }^{[18]}$ Studies reported that the average infectious period was 10 days ${ }^{[20]}$ with $30 \%$ of the cases showing no symptoms. ${ }^{[21]}$ As per the estimates given in literatures, around $80 \%$ of symptomatic persons experience mild disease, $20 \%$ experience severe disease; $5 \%$ need admission in ICU and $3.8 \%$ of them may die due to COVID-19. ${ }^{[18,22]}$

Existing literature gave basic reproductive rate in broad range. Rocklöv $\mathbf{J}$ et al estimated the basic reproductive rate to be 14.8 , before taking any control measure in Diamond Princes cruise ship. ${ }^{[14]}$ Studies from other parts of Wuhan were given basic reproductive rate in range of 2.2 to 6.47 with mean of $3.28 .^{[23]}$ Based on these evidences, we estimated the basic reproductive rate for Delhi by adjusting for the difference in the population density.

We classified the contacts of cases into household contacts, contacts in hubs (contacts in workplace and public gatherings), and community contacts (neighbours, contacts during travelling and other outdoor activities). We used estimates of SARS-Cov 2 to obtain the proportion of cases resulted from each type of contact [Table I]. ${ }^{[24]}$ We considered all interventions, government of Delhi implemented and isolation of both case and contacts to estimate the burden of COVID-19 in Delhi. In social distancing intervention, we assume at least $50 \%$ of the individuals have followed the intervention in community and its effect is negligible in workplace and house due to repeated contact and closed environment. We 
considered 4 days delay in case isolation ${ }^{[4,25]}$ due to delay in health care seeking ( 2 days), sample collection, transport (1 day), testing and reporting (1 day). To estimate the reduction fraction in case isolation we subtracted the days of delay in case isolation from total infectious period, assuming equal probability of transmission of the virus throughout the infectious period in workplace and community contact. In lockdown intervention (closure of workplace except for essential services, educational institutes, recreational sites, banning of public gathering, stopping of transportation except for essential services), we considered all people stay at home, thus, have nil effect on house hold contacts, But reduce $90 \%$ of workplace transmission (since $10 \%$ may occur during provision of essential services) and community transmission similar to social distancing (people continued maintain contact in closed communities) [Table I].

In Delhi, case isolation was implemented from day zero, social distancing was implemented from day 15 and lockdown was implemented from day 20 after reporting of the index case. ${ }^{[26,27]}$ For social distancing and lockdown we assumed that the effect of intervention may be shown after 7 days (half of maximum incubation period) of implementing intervention.

\section{Sensitivity analysis:}

We have done sensitivity analysis for variation in the proportion of asymptomatic cases. For the purpose of sensitivity analysis, variation in proportion of asymptomatic cases was adopted from study conducted by Nishiura $\mathrm{H}$ et al. ${ }^{[21]}$ Variation in asymptomatic cases affects the estimation when case targeted interventions implemented. Therefore we conducted sensitivity analysis for variations in asymptomatic cases when scenarios included case isolation intervention.

Ethics: There are no ethical concerns related to the study since all the data are taken from the official public domain from the respective institutions. 
medRxiv preprint doi: https://doi.org/10.1101/2020.05.01.20087783; this version posted May 10, 2020. The copyright holder for this preprint

\section{Results:}

In the study, we estimated the $\mathrm{R}_{0}$ first. Mean $\mathrm{R}_{0}$ for Delhi population was estimated to be 6.18 and it ranges from 4.15 to 12.2 . We also estimated the effective reproductive rate $\left(R_{t}\right)$ for different intervention. Least $\mathrm{R}_{\mathrm{t}}$ was seen when isolation of cases and contacts are strictly implemented followed by lockdown combined with case isolation [Table II].

We estimated the effect of interventions social distancing, lockdown and case isolation separately as well as in combination as they were implemented by the government of Delhi. The study estimated that the outbreak will reach its peak in 94 days, if no interventions are implemented. The peak of the epidemic curve can be delayed by 4 days if only social distancing was implemented, by 35 days when only lockdown was implemented, by 31 days when only case isolation is implemented. The same will delay by 35 days when case isolation along with social distancing was implemented, by 28 days when case isolation with 21 days lockdown was implemented and by 69 days when case isolation along with continued lockdown is implemented. When individual interventions were considered, lockdown had the maximum effect on pandemic [Figure 1]. Lockdown alone reduced the maximum number of prevalent cases on peak day, mean of prevalent cases per day, and mean number of patients needed ICU per day by $28 \%, 22 \%$ and $22 \%$, respectively, by reducing the transmission at workplace and community contacts [Figure 3].

It was observed that various interventions implemented in combination would delay the peak of pandemic and flatten the pandemic curve. In the intervention of case isolation with social distancing, peak of pandemic occurs 3 days earlier as compared to case isolation with lockdown for 21 days. But reduction in number of prevalent cases per day and reduction in mean of number of patients needed ICU admission was higher in case isolation with social distancing (28\% and $22 \%$, respectively) compared to case isolation with lockdown for 21 
medRxiv preprint doi: https://doi.org/10.1101/2020.05.01.20087783; this version posted May 10, 2020. The copyright holder for this preprint

days (25\% and $22 \%$, respectively). Case isolation with continued lockdown reduced the number of prevalent cases on peak day by $50 \%$ and showed mean reduction of ICU beds by $42 \%$. Details of the effect of various public health interventions on COVID-19 outbreak are given in table III.

The study also estimated the number of asymptomatic cases, symptomatic cases with mild infection, severe infection and patients in need of ICU care, which are shown in figure 3 of supplementary material. It is estimated that around 193,843 patients need ICU care on peak day of pandemic which can be reduced 97436 if we implement case isolation and continue the lockdown. Figure 4 shows the comparison of actual number of confirmed COVID-19 cases in Delhi with the estimated numbers till 30.04.2020. Sensitivity analysis showed that if asymptomatic (hidden) cases are less, all individual level interventions showed maximum effect [Figure 2]. When proportion of asymptomatic cases was 7\%, case isolation delayed the peak of pandemic by 53 days with $41 \%$ reduction in prevalent cases on peak day and case isolation with continued lockdown delayed the peak by 93 days with $60 \%$ reduction in prevalent cases. When proportion of asymptomatic cases was 53\%, case isolation alone and in combination with continued lockdown, delayed the pandemic by 22 days with $18 \%$ reduction in prevalent cases on peak day and by 52 days with $41 \%$ reduction in prevalent cases, respectively.

\section{Discussion:}

The results of our study forecast the possible course of the pandemic in the National Capital Region of Delhi and the likely effect of various public health interventions considered by the Government of India and the Government of Delhi. Accordingly estimates shows that pandemic may reach its peak on $94^{\text {th }}$ day with around 55 lakh prevalent cases on peak day, if no public health interventions implemented. By case isolation and lockdown we could delay 
medRxiv preprint doi: https://doi.org/10.1101/2020.05.01.20087783; this version posted May 10, 2020. The copyright holder for this preprint

the pandemic by 69 days with around 28 lakh (50\% reduction) prevalent cases on the peak day.

Before forecasting the course of pandemic, we estimated the basic reproductive rate $\left(\mathrm{R}_{0}\right)$ for Delhi to be 6.18 (range $4.15-12.2$ ). ${ }^{[23]}$ Based on data obtained from diamond prince ship, $\mathrm{R}_{0}$ was estimated to be $14.7 .^{[14]}$ The difference in estimated $\mathrm{R}_{0}$ might be due to the variation in population density. Population density of Delhi was 11320 whereas the population density of Diamond Prince Ship was $24400 .^{[14,16]}$ If we adjust to population density then $R_{0} 14.7$ in cruise ship is equivalent to $\mathrm{R}_{0} 6.86$ in Delhi, which is comparable to the estimates in our study. However, the model has not considered the difference in contact rate among people, which may lead to slight variations in the $\mathrm{R}_{0}$. We preferred the $\mathrm{R}_{0}$ estimate based on evidence from Wuhan for forecasting the pandemic in Delhi, as these estimates were based on data obtained before any large scale community interventions were implemented.

Our study estimated that the outbreak will reach its peak in 94 days, if no interventions are implemented. When interventions implemented separately, lockdown showed maximum effect with delaying the pandemic by 35 days and when implemented in combination case isolation with continued lockdown showed the maximum effect. Lockdown alone was able to reduce number prevalent cases on peak day of pandemic by $28 \%$, where case isolation alone reduced by $25 \%$ and social distancing alone reduced by $3 \%$. These findings showed that lockdown had the maximum effect on the transmission of disease. Case isolation showed the maximum effect on reproductive rate in our estimations. These differences were mainly due to the effect of asymptomatic cases. Currently, majority of the countries are testing only the symptomatic cases and the same is applicable to Delhi also. The asymptomatic cases who will not be identified and isolated will continue to transmit the disease in the community. ${ }^{[25]}$ Therefore the effect of case isolation decreased due to asymptomatic cases. Lockdown is a community-level intervention which is applied to everyone irrespective of their disease 
medRxiv preprint doi: https://doi.org/10.1101/2020.05.01.20087783; this version posted May 10, 2020. The copyright holder for this preprint

status. This will decrease the transmission from both asymptomatic and symptomatic cases. We incorporated these points into the model while estimating the number of prevalent cases. In sensitivity analysis, it was shown that when the proportion of asymptomatic cases decreased, the effect of case isolation increased. To decrease the number of hidden cases and case isolation to be successful, we need to increase the diagnostic testing capacity of health system for COVID-19. These findings also highlight that due to high proportion of asymptomatic cases and limited capacity of health system to trace and test all contacts of positive cases; case-based interventions are having limited scope in flattening epidemic curve. To have a better outcome we need to combine both case-based and community-based approach. These findings are further supported by evidences from European countries, compiled by imperial collage COVID-19 response team. ${ }^{[28]}$ The study conducted by Koo et al also showed that combined interventions including case based approach and community level interventions were more successful in flattening the pandemic curve. ${ }^{[29]}$

The findings suggests that, even though lockdown showing better results compared to other interventions, implementing it for short duration would not show the better results. Case isolation with lockdown for 21 days delayed peak of pandemic by 3 more days compared to case isolation combined with social distancing but still showed higher number of prevalent cases on peak day. To have better outcome lockdown should be continued for longer duration. If it implemented for short duration, loss may outweighs the benefits of the intervention.

The strength of SEIR model is that, it is a tested model to estimate the size of outbreak with local transmission. It gives good estimates of outbreak in a defined population, which helps in planning and policy making to control the outbreak in the population. It also provides us the rate of increase or decrease in number of cases which is very useful to understand the dynamics of outbreak. The model considers that the disease starts from single foci and 
spreads to the rest of the population. In current scenario, we have multiple imported cases which could have affected the results. However, we added the imported cases (who had travel history and diagnosed to be COVID-19 positive in Delhi) on the day of reporting to infected pool.

The present model also has a few limitations. The populations living in a rapidly developing new metropolis may be highly heterogeneous due to caste, religion or economic power, and if that affects the basic reproductive rate in significant scale, the estimates might vary. However, the NCR is a well-developed and rather stable metropolis and we believe it is relatively less heterogeneous in nature than many two tier towns in the country and thus will have lesser effect on the estimates. ${ }^{[16]}$ Literatures were uncertain about when the infected person starts to shed the virus, and the most commonly found time is 12 hours before symptoms appear. ${ }^{[20]}$ We had assumed that at the end of incubation period, infected person starts to shed the virus which applied for both symptomatic and asymptomatic cases.

In summary, interventions implemented in Delhi are time buying interventions to prepare and act to mitigate the effect of pandemic and to make it manageable. Interventions should be implemented in combinations of individual level and community level interventions to gain better outcome. Identifying and isolation of all cases as early as possible is important to flatten the pandemic curve.

Acknowledgement: Nil

Financial support: Nil

Conflict of Interest: None declared

\section{References:}

1. Peiris JSM, Guan Y, Yuen KY. Severe acute respiratory syndrome [Internet]. Nat. 
Med.2004 [cited 2020 Apr 15];10(12S):S88-97. Available from:

http://www.ncbi.nlm.nih.gov/pubmed/15577937

2. Huang C, Wang Y, Li X, Ren L, Zhao J, Hu Y, et al. Clinical features of patients infected with 2019 novel coronavirus in Wuhan, China. Lancet [Internet] 2020 [cited 2020 Mar 27];395(10223):497-506. Available from:

https://www.thelancet.com/pdfs/journals/lancet/PIIS0140-6736(20)30183-5.pdf

3. WHO. WHO Timeline - COVID-19 [Internet]. 2020 [cited 2020 Apr 15];Available from: https://www.who.int/news-room/detail/08-04-2020-who-timeline---covid-19

4. $\quad$ Li Q, Guan X, Wu P, Wang X, Zhou L, Tong Y, et al. Early Transmission Dynamics in Wuhan, China, of Novel Coronavirus-Infected Pneumonia. N Engl J Med 2020;382(13):1199-207.

5. WHO. Pneumonia of unknown cause-China [Internet]. 2020 [cited 2020 Apr 15];Available from: https://www.who.int/csr/don/05-january-2020-pneumonia-ofunkown-cause-china/en/

6. WHO. Novel Coronavirus (2019-nCoV) SITUATION REPORT - 3 [Internet]. 2020 [cited 2020 Apr 16]. Available from: https://www.who.int/docs/defaultsource/coronaviruse/situation-reports/20200123-sitrep-3-2019ncov.pdf?sfvrsn=d6d23643_8

7. WHO. Coronavirus disease 2019 (COVID-19) Situation Report-55 [Internet]. Geneva: 2020 [cited 2020 Apr 16]. Available from: https://www.who.int/docs/defaultsource/coronaviruse/situation-reports/20200315-sitrep-55-covid19.pdf?sfvrsn=33daa5cb_8

8. BBC. China's travel industry counts cost of coronavirus [Internet]. 2020 [cited 2020 
medRxiv preprint doi: https://doi.org/10.1101/2020.05.01.20087783; this version posted May 10, 2020. The copyright holder for this preprint (which was not certified by peer review) is the author/funder, who has granted medRxiv a license to display the preprint in perpetuity.

It is made available under a CC-BY-NC-ND 4.0 International license .

Apr 16];Available from: https://www.bbc.com/news/business-51232374

9. BBC. Coronavirus: Wuhan shuts public transport over outbreak - BBC News

[Internet]. 2020 [cited 2020 Apr 16];Available from:

https://www.bbc.com/news/world-asia-china-51215348

10. Ministry of Health and Family Welfare. COVID-19 India [Internet]. Gov. India2020

[cited 2020 Apr 22];Available from: https://www.mohfw.gov.in/

11. Predictions and role of interventions for COVID-19 outbreak in India [Internet]. 2020

[cited 2020 Mar 26];Available from: https://medium.com/@ covind_19/predictions-

and-role-of-interventions-for-covid-19-outbreak-in-india-52903e2544e6

12. Mandal S, Bhatnagar T, Arinaminpathy N, Agarwal A, Chowdhury A, Murhekar M, et

al. Prudent public health intervention strategies to control the coronavirus disease 2019

transmission in India: A mathematical model-based approach. Indian J Med Res

[Internet] 2020 [cited 2020 Apr 23];Available from:

http://www.ncbi.nlm.nih.gov/pubmed/32202261

13. Vynnycky E, White RG. An introduction to infectious disease modelling. 1st ed.

Oxford University Press; 2010.

14. Rocklöv J, Sjödin H, Wilder-Smith A. COVID-19 outbreak on the Diamond Princess cruise ship: estimating the epidemic potential and effectiveness of public health countermeasures. J Travel Med [Internet] 2020 [cited 2020 Apr 16];taaa030. Available from: https://academic.oup.com/jtm/article/doi/10.1093/jtm/taaa030/5766334

15. Yaesoubi R, Cohen T. Generalized Markov models of infectious disease spread: A novel framework for developing dynamic health policies. Eur J Oper Res [Internet] 2011 [cited 2020 Apr 16];215(3):679-87. Available from: 
medRxiv preprint doi: https://doi.org/10.1101/2020.05.01.20087783; this version posted May 10, 2020. The copyright holder for this preprint (which was not certified by peer review) is the author/funder, who has granted medRxiv a license to display the preprint in perpetuity.

It is made available under a CC-BY-NC-ND 4.0 International license .

https://www.ncbi.nlm.nih.gov/pmc/articles/PMC3182455/

16. Census of India 2011. Provisional Population Totals NCT of Delhi [Internet]. Mumbai: 2011 [cited 2020 Apr 16]. Available from: http://censusindia.gov.in/2011-provresults/data_files/delhi/3_PDFC-Paper-1-tables_60_81.pdf

17. Census of India. Sample Registration System Statistical Report 2019 [Internet]. 2019. Available from: http://censusindia.gov.in/vital_statistics/SRS_Bulletins/SRS_BulletinRate-2017-_May_2019.pdf

18. Adhikari SP, Meng S, Wu Y-J, Mao Y-P, Ye R-X, Wang Q-Z, et al. Epidemiology, causes, clinical manifestation and diagnosis, prevention and control of coronavirus disease (COVID-19) during the early outbreak period: a scoping review. Infect Dis poverty [Internet] 2020 [cited 2020 Mar 26];9(1):29. Available from: http://www.ncbi.nlm.nih.gov/pubmed/32183901

19. WHO. Coronavirus disease 2019 (COVID-19) Situation Report-73 [Internet]. Geneva: 2020 [cited 2020 Apr 16]. Available from: https://www.who.int/docs/defaultsource/coronaviruse/situation-reports/20200402-sitrep-73-covid19.pdf?sfvrsn=5ae25bc7_6

20. Liu Y, Yan L-M, Wan L, Xiang T-X, Le A, Liu J-M, et al. Viral dynamics in mild and severe cases of COVID-19. Lancet Infect Dis [Internet] 2020 [cited 2020 Apr 16];Available from: https://www.thelancet.com/action/showPdf?pii=S1473$3099 \% 2820 \% 2930232-2$

21. Nishiura H, Kobayashi T, Suzuki A, Jung S-M, Hayashi K, Kinoshita R, et al. Estimation of the asymptomatic ratio of novel coronavirus infections (COVID-19). Int J Infect Dis [Internet] 2020 [cited 2020 Apr 16];Available from: https://doi.org/10.1016/j.ijid.2020.03.020 
medRxiv preprint doi: https://doi.org/10.1101/2020.05.01.20087783; this version posted May 10, 2020. The copyright holder for this preprint (which was not certified by peer review) is the author/funder, who has granted medRxiv a license to display the preprint in perpetuity.

It is made available under a CC-BY-NC-ND 4.0 International license .

22. WHO. Coronavirus disease 2019 (COVID-19) Situation Report-30 [Internet]. Geneva: 2020 [cited 2020 Apr 16]. Available from: https://www.who.int/docs/defaultsource/coronaviruse/situation-reports/20200219-sitrep-30-covid19.pdf?sfvrsn=3346b04f_2

23. Liu Y, Gayle AA, Wilder-Smith A, Rocklöv J. The reproductive number of COVID-19 is higher compared to SARS coronavirus. J Travel Med 2020;27(2):1-4.

24. Milne GJ, Baskaran P, Halder N, Karl S, Kelso J. Pandemic influenza in papua new guinea: A modelling study comparison with pandemic spread in a developed country. BMJ Open 2013;3(3):1-10.

25. Song J-Y, Yun J-G, Noh J-Y, Cheong H-J, Kim W-J. Covid-19 in South KoreaChallenges of Subclinical Manifestations. N Engl J Med [Internet] 2020 [cited 2020 Apr 15];Available from: https://www.nejm.org/doi/pdf/10.1056/NEJMc2001801?articleTools=true

26. Ministry of Health \& Family Welfare. Advisory on Social Distancing Measure in view of spread of COVID-19 disease [Internet]. 2020 [cited 2020 Apr 16];8-9. Available from: https://www.mohfw.gov.in/pdf/SocialDistancingAdvisorybyMOHFW.pdf

27. Government of National Capital Territory of Delhi H\& FWD. Government of national capital territory of delhi health \& family welfare department [Internet]. India: 2020. Available from: http://health.delhigovt.nic.in/wps/wcm/connect/deaf86804da4c3bb8687f7982ee7a5c7/1 ock.pdf?MOD=AJPERES\&lmod=48689189\&CACHEID=deaf86804da4c3bb8687f79 $82 \mathrm{ee} 7 \mathrm{a} 5 \mathrm{c} 7$

28. Flaxman S, Mishra S, Gandy A, Unwin JT, Coupland H, Mellan TA, et al. Report 13: Estimating the number of infections and the impact of non-pharmaceutical 
medRxiv preprint doi: https://doi.org/10.1101/2020.05.01.20087783; this version posted May 10, 2020. The copyright holder for this preprint (which was not certified by peer review) is the author/funder, who has granted medRxiv a license to display the preprint in perpetuity. It is made available under a CC-BY-NC-ND 4.0 International license.

interventions on COVID-19 in 11 European countries [Internet]. London: 2020 [cited 2020 Apr 16]. Available from: https://doi.org/10.25561/77731

29. Koo JR, Cook AR, Park M, Sun Y, Sun H, Lim JT, et al. Interventions to mitigate early spread of SARS-CoV-2 in Singapore $\square$ : a modelling study. Lancet Infect Dis [Internet] 2020 [cited 2020 Apr 16];3099(20):1-11. Available from: http://dx.doi.org/10.1016/S1473-3099(20)30162-6 


\begin{tabular}{|c|c|c|c|c|c|c|}
\hline \multicolumn{7}{|c|}{$\begin{array}{l}\text { Table I: Contribution to case pool and effec } \\
\text { among contact groups of COVID-19 cases }\end{array}$} \\
\hline \multirow[b]{2}{*}{ Illness acquired at } & \multirow[b]{2}{*}{$\begin{array}{l}\text { Proportion } \\
\text { contributed } \\
\text { to case } \\
\text { pool }^{[24]}\end{array}$} & \multicolumn{5}{|c|}{ Reduction achieved by intervention } \\
\hline & & $\begin{array}{l}\text { Social } \\
\text { distancing }\end{array}$ & $\begin{array}{l}\text { Lock } \\
\text { down }\end{array}$ & $\begin{array}{l}\text { case } \\
\text { isolation }\end{array}$ & $\begin{array}{l}\text { case } \\
\text { isolation } \\
+ \text { Lock } \\
\text { down }\end{array}$ & $\begin{array}{l}\text { case } \\
\text { isolation } \\
+ \text { Social } \\
\text { distancing }\end{array}$ \\
\hline Household contact & 48.7 & 0 & 0 & 25 & 25 & 25 \\
\hline $\begin{array}{l}\text { Workplace and } \\
\text { hubs contact }\end{array}$ & 30.5 & 0 & 90 & 60 & 96 & 60 \\
\hline Community contact & 20.8 & 25 & 25 & 60 & 70 & 70 \\
\hline $\begin{array}{l}\text { Total reduction } \\
\text { achieved }\end{array}$ & & 5.2 & 32.65 & 42.95 & 56.01 & 45.03 \\
\hline $\begin{array}{l}\text { With the current resp } \\
\text { compliance to social }\end{array}$ & $\begin{array}{l}\text { nse from th } \\
\text { istancing. }\end{array}$ & population & e assun & $\mathrm{d}$ at leas & $0 \%$ shov & the \\
\hline
\end{tabular}


medRxiv preprint doi: https://doi.org/10.1101/2020.05.01.20087783; this version posted May 10, 2020. The copyright holder for this preprint (which was not certified by peer review) is the author/funder, who has granted medRxiv a license to display the preprint in perpetuity.

It is made available under a CC-BY-NC-ND 4.0 International license .

\section{Table II: Estimated basic reproductive rate and effective reproductive rate of COVID-19 in Delhi population}

\begin{tabular}{|c|c|c|}
\hline \multicolumn{2}{|l|}{ Parameters } & Estimates \\
\hline \multicolumn{2}{|c|}{ Mean basic reproductive rate } & 6.18 \\
\hline \multicolumn{2}{|c|}{ Minimum basic reproductive rate } & 4.15 \\
\hline \multicolumn{2}{|c|}{ Maximum basic reproductive rate } & 12.2 \\
\hline \multirow{6}{*}{$\begin{array}{l}\text { Effective } \\
\text { reproductive } \\
\text { rate }\end{array}$} & Social distancing & 5.86 \\
\hline & Lockdown & 4.16 \\
\hline & Case isolation & 3.56 \\
\hline & Case isolation and social distancing & 3.40 \\
\hline & Case isolation and lock down & 2.72 \\
\hline & Case and contact isolation & 1.62 \\
\hline
\end{tabular}




\section{Table III: Effect of public health interventions on COVID-19 pandemic in Delhi}

\begin{tabular}{|c|c|c|c|c|c|c|c|}
\hline Interventions & $\begin{array}{l}\text { no } \\
\text { intervention }\end{array}$ & $\begin{array}{l}\text { Social } \\
\text { distancing }\end{array}$ & $\begin{array}{l}\text { Lock } \\
\text { down }\end{array}$ & $\begin{array}{l}\text { case } \\
\text { isolation }\end{array}$ & $\begin{array}{l}\text { case } \\
\text { isolation } \\
\text { with social } \\
\text { distancing }\end{array}$ & $\begin{array}{l}\text { case } \\
\text { isolation } \\
\text { with } 21 \\
\text { day lock } \\
\text { down }\end{array}$ & $\begin{array}{l}\text { Case } \\
\text { isolation } \\
\text { with } \\
\text { continued } \\
\text { lock } \\
\text { down }\end{array}$ \\
\hline $\begin{array}{l}\text { Days to reach Peak } \\
\text { of pandemic }\end{array}$ & 94 & 98 & 129 & 125 & 129 & 132 & 163 \\
\hline $\begin{array}{l}\text { Maximum number } \\
\text { of prevalent } \\
\text { cases/day (on peak } \\
\text { day) }\end{array}$ & 5538364 & 5347571 & 3993430 & 4136277 & 3972078 & 4136017 & 2783885 \\
\hline $\begin{array}{l}\text { reduction in } \\
\text { Maximum number } \\
\text { of prevalent } \\
\text { cases/day (on peak } \\
\text { day) }\end{array}$ & & 3 & 28 & 25 & 28 & 25 & 50 \\
\hline $\begin{array}{l}\text { Mean of prevalent } \\
\text { cases/day }\end{array}$ & 626525 & 610373 & 487840 & 501683 & 485857 & 490354 & 363151 \\
\hline $\begin{array}{l}\text { reduction in mean } \\
\text { of prevalent cases }\end{array}$ & & 3 & 22 & 20 & 22 & 22 & 42 \\
\hline $\begin{array}{l}\text { maximum number } \\
\text { of severe cases/day }\end{array}$ & 581528 & 561495 & 419310 & 434309 & 417068 & 434282 & 292308 \\
\hline $\begin{array}{l}\text { Mean of sever } \\
\text { cases/day }\end{array}$ & 65785 & 64089 & 51223 & 52677 & 51015 & 51487 & 38131 \\
\hline $\begin{array}{l}\text { Maximum number } \\
\text { of patients needed } \\
\text { ICU admission }\end{array}$ & 193843 & 187165 & 139770 & 144770 & 139023 & 144761 & 97436 \\
\hline $\begin{array}{l}\text { Reduction in } \\
\text { Maximum number } \\
\text { of patients needed } \\
\text { ICU admission in } \\
\text { single day }\end{array}$ & & 3 & 28 & 25 & 28 & 25 & 50 \\
\hline $\begin{array}{l}\text { mean of patients } \\
\text { needed ICU }\end{array}$ & 21928 & 21363 & 17074 & 17559 & 17005 & 17162 & 12710 \\
\hline $\begin{array}{l}\text { Reduction in ICU } \\
\text { needed }\end{array}$ & & 3 & 22 & 20 & 22 & 22 & 42 \\
\hline
\end{tabular}


Figure 1: Estimation of COVID-19 cases using SEIR model in various public health interventions

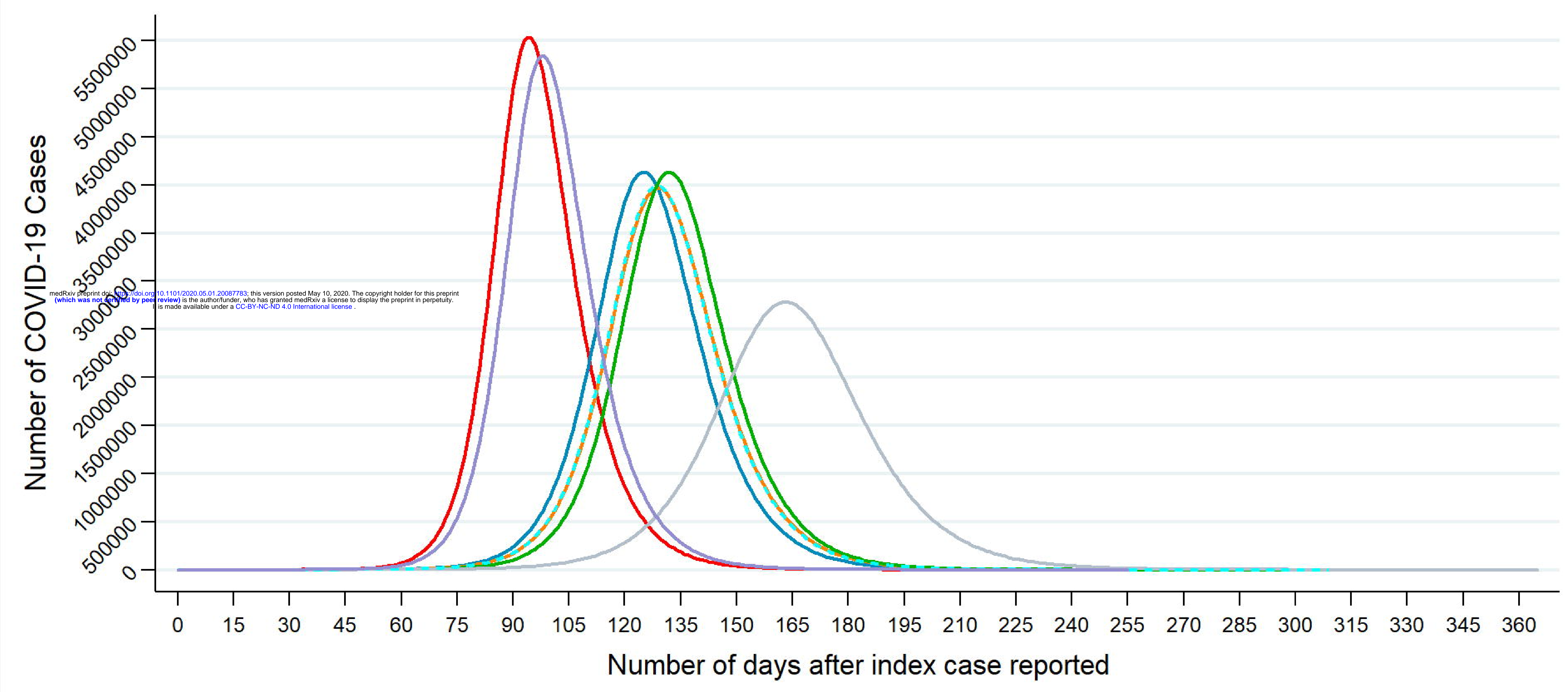

No intervention

Case isolation and social distancing

Case isolation and continued lockdown

Social distancing only
Case isolation only

Case isolation and lock down for 21 days Lock down only 


\section{Figure 2: Sensitivity analysis for proportion of asymptomatic cases}

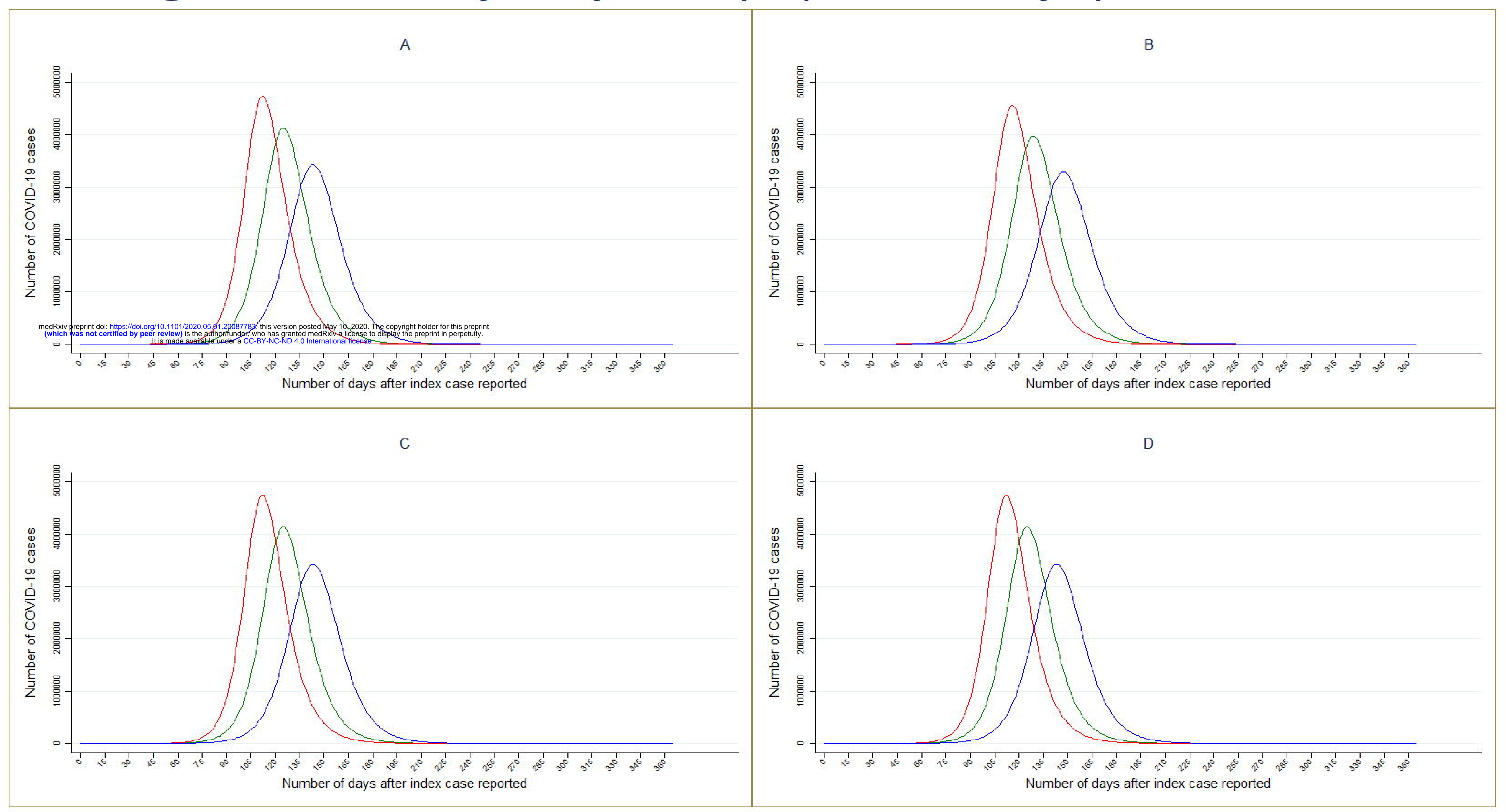

$30 \%$ asymptomatic

$53 \%$ asymptomatic

$7 \%$ asymptomatic

A: Only Case Isolation, B: Case Isolation+Social Distancing,

C: Case Isolation+Social Distancing+21days lockdown, D: Case Isolation+Social Distancing+ continued lockdown 


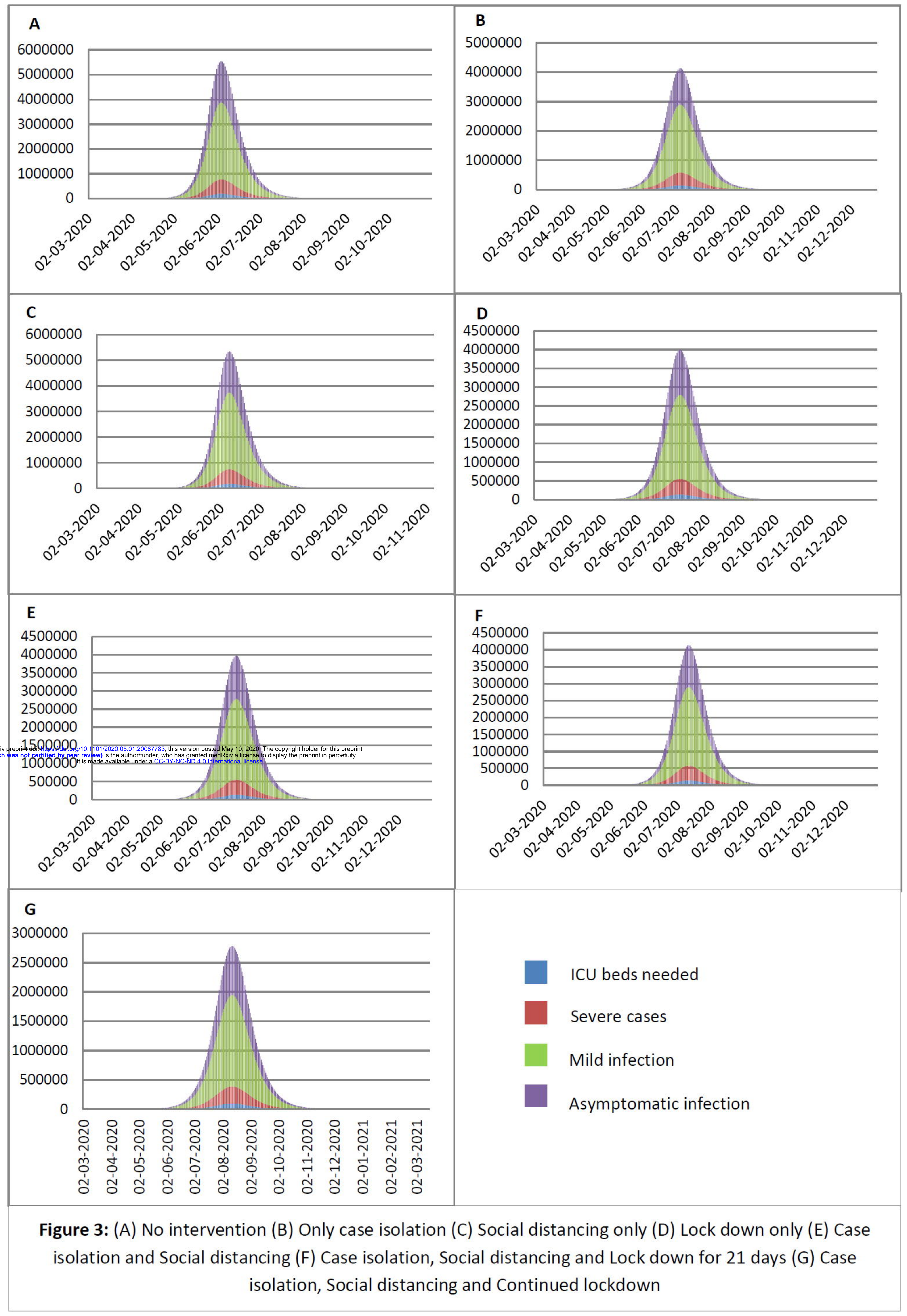


Figure 4: Comparison betweeen actual and estimated cases in Delhi till 30.04.2020

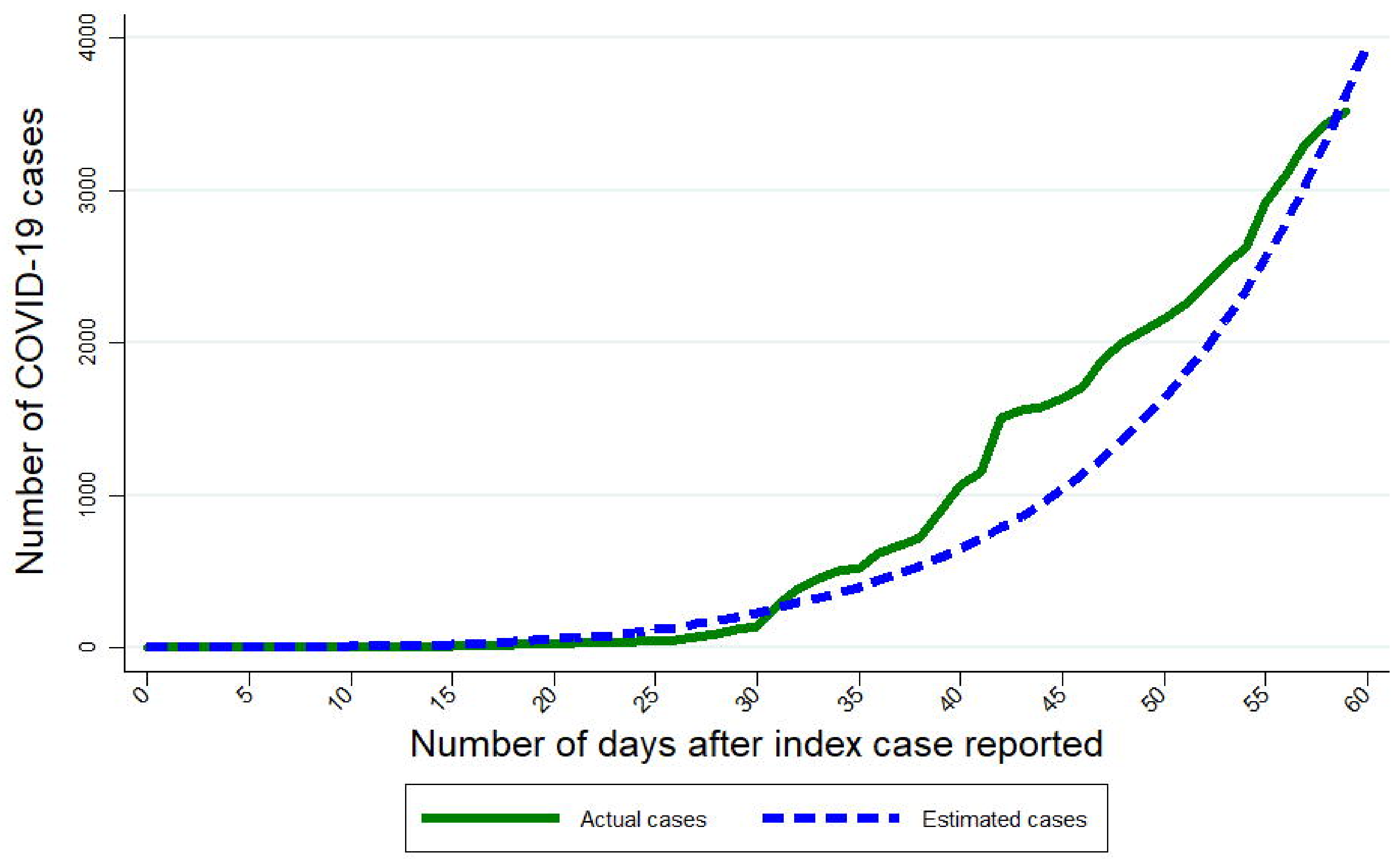

